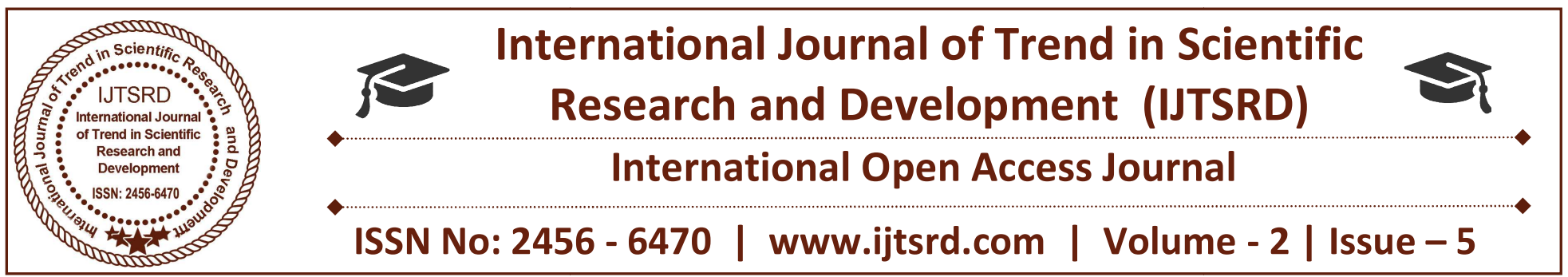

\title{
Benefits and Constraints of Rice Mechanization in Thamirabarani Command Area of Tamil Nadu
}

\author{
P. Panneer Selvam ${ }^{1}$, Dr. S. Somasundaram ${ }^{2}$ \\ ${ }^{1}$ M.Sc. ( Agricultural) Student, ${ }^{2}$ Professor (Agricultural Extension) \\ Tamil Nadu Agricultural University, Department of Social Sciences, \\ Agricultural College and Research Institute, Killikulam, Vallanad, Tamil Nadu, India
}

\section{ABSTRACT}

The study was aimed to assess the perceived opinion of rice growers on benefits and also the constraints encountered by the rice growers on farm mechanization. A sample of 160 rice growers from eight villages in Thamirabarani command area was selected for the study. The respondents were interviewed personally through a well-structured and pre-tested interview schedule. The study revealed that the Overall Mean Opinion Score was 3.91 which indicated that farm mechanization was beneficial to the rice growers in many aspects. The major benefits of farm mechanization as perceived by the respondents were farm mechanization helped in operating agricultural works quickly (MOS 4.97), performing farm operations in time (MOS 4.86), overcoming labour shortage problem (MOS 4.75), minimizing work burden of labours (MOS 4.61) and improving working condition of farmers (MOS 4.03). Regarding constraints, most of the respondents expressed lack of credit facilities ( 98.75 per cent), high fuel cost ( 98.75 per cent), high initial cost ( 97.50 per cent), low resale value for farm implements and machineries ( 97.50 per cent), high maintenance cost (95.00 per cent), lack of training ( 94.38 per cent) and lack of skilled labourers for operating improved farm implements and machineries (93.13 per cent) as the constraints in rice mechanization.

Keywords: Rice, farm mechanization, perceived opinion on benefits, constraints.

\section{INTRODUCTION}

Agricultural mechanization technology plays a key role in improving agricultural production in developing countries, and should be considered as an essential input to agriculture (Rasouli et al. 2009). Farm mechanization refers to application of engineering and technology in agricultural operations in a better way to enhance the productivity. This includes development, application and management of all mechanical aids for field operation, water control, material handling, storing and processing. Mechanical aids include hand tools, animal drawn implements, machineries like power tiller, tractor, oil engines, electric motors, combine harvesters, processing and handling equipment.

The food grain production of India during 2015-16 was 252 million tonnes. The ICAR in its Vision 2020 document has projected the demand of food grains as about 293.6 million tonnes by 2020 . By 2020, the workforce in agriculture is going to be reduced to about 35 per cent of the total workers in the country as against 52 per cent in 2010. Therefore, higher levels of farm mechanization are necessary to optimise productivities and profitability.

Empirical evidence confirms that there is a strong correlation between farm mechanization and agricultural productivity. Globally, the level of farm mechanization is 95 per cent in USA and Western Europe, 80 per cent in Russia, 75 per cent in Brazil, 48 per cent in China and 40 per cent in India. Indian agricultural sector still lags and requires an increase in farm equipment.

Rice is one of the most important food crops and it is consumed by more than 60 per cent population in our 
country. In Tamil Nadu, next to Cauvery delta, rice is cultivated more in Thambirabarani command area. The rice farmers are facing a lot of problems in rice cultivation mainly due to acute labour shortage and rice mechanization is on progress in this area. Hence, it becomes essential to understand the perceived opinion on benefits and constraints of farm mechanization pertaining to rice cultivation.

\section{Methodology}

The study was conducted in Thamirabarani command area of Tamil Nadu. The river flows through two districts Tirunelveli and Thoothukudi and both the districts were selected for the study. Two blocks in Tirunelveli district and another two blocks in Thoothukudi district were selected for the study based on the maximum area under rice cultivation. Two villages in each selected block based on maximum area under rice cultivation were identified and thus, eight villages were selected for the study. A sample size of 160 rice farmers was fixed as respondents and the 160 respondents were identified from the selected eight villages by applying proportionate random sampling method. The respondents were interviewed personally through a well-structured and pre-tested interview schedule.

For identifying the perceived opinion of farmers on benefits of farm mechanization, the benefits were listed out by perusing the literature and also in consultation with the scientists of TNAU, extension personnel of State Department of Agriculture, extension personnel of State Department of Agricultural Engineering and progressive farmers.
The list was fine-tuned during pre-test and finalised. The scoring procedure adopted by (Thakur and Sharma, 2016) was used in this study with slight modification. The scoring procedure is given below.

\begin{tabular}{|c|c|c|c|c|c|}
\hline $\begin{array}{c}\text { Benef } \\
\text { its }\end{array}$ & $\begin{array}{c}\text { Stron } \\
\text { gly } \\
\text { Agree }\end{array}$ & $\begin{array}{c}\text { Agr } \\
\text { ee }\end{array}$ & $\begin{array}{c}\text { Undeci } \\
\text { ded }\end{array}$ & $\begin{array}{c}\text { Disagr } \\
\text { ee }\end{array}$ & $\begin{array}{c}\text { Strong } \\
\text { ly } \\
\text { Disagr } \\
\text { ee }\end{array}$ \\
\hline $\begin{array}{c}\text { Scores } \\
\text { for } \\
\text { items }\end{array}$ & 5 & 4 & 3 & 2 & 1 \\
\hline
\end{tabular}

Mean score and percentage analysis was used to get the meaningful interpretation about the perceived opinion on the benefits of farm mechanization in rice cultivation.

As regards to constraints, the possible constraints were enumerated from related studies, consultation with the biological and social scientists, extension personnel and the farmers of non-sample area. The respondents were asked to give their responses whetherthey had faced the constraints in the previous years. The results were interpreted in percentage.

\section{Results and Discussion}

\subsection{Perceived opinion of farmers on benefits of mechanization}

Fifteen benefits of mechanization on rice cultivation were identified. Data on farmers' perception on the identified benefits of mechanization were collected and is presented in Table 1.

Table 1.Perceived opinion of farmers on benefits of mechanization

\begin{tabular}{|c|c|c|c|c|c|c|c|c|}
\hline $\begin{array}{c}\text { S. } \\
\text { No }\end{array}$ & $\begin{array}{c}\text { Benefits of } \\
\text { mechanization }\end{array}$ & $\begin{array}{c}\text { Strongly } \\
\text { Agree }\end{array}$ & $\begin{array}{c}\text { Agree } \\
\text { Undeci } \\
\text { ded }\end{array}$ & Disagree & $\begin{array}{c}\text { Strongly } \\
\text { Disagree }\end{array}$ & TOS* & MOS* \\
\hline 1. & $\begin{array}{c}\text { Operating agricultural } \\
\text { works quickly }\end{array}$ & $\begin{array}{c}155 \\
(96.88)\end{array}$ & $\begin{array}{c}5 \\
(3.12)\end{array}$ & - & - & - & 795 & 4.97 \\
\hline 2. & $\begin{array}{c}\text { Performing farm } \\
\text { operations in time }\end{array}$ & $\begin{array}{c}138 \\
(86.25)\end{array}$ & $\begin{array}{c}22 \\
(13.75)\end{array}$ & - & - & - & 778 & 4.86 \\
\hline 3. & $\begin{array}{c}\text { Overcoming labour } \\
\text { shortage problem }\end{array}$ & $\begin{array}{c}120 \\
(75.00)\end{array}$ & $\begin{array}{c}40 \\
(25.00)\end{array}$ & & & & 760 & 4.75 \\
\hline 4. & $\begin{array}{c}\text { Minimizing work } \\
\text { burden of labourers }\end{array}$ & $\begin{array}{c}98 \\
(61.25\end{array}$ & $\begin{array}{c}62 \\
(38.75)\end{array}$ & - & - & - & 738 & 4.61 \\
\hline 5. & $\begin{array}{c}\text { Improving working } \\
\text { condition of farmers }\end{array}$ & $\begin{array}{c}4 \\
(2.50)\end{array}$ & $\begin{array}{c}156 \\
(97.50)\end{array}$ & - & - & - & 644 & 4.03 \\
\hline
\end{tabular}


International Journal of Trend in Scientific Research and Development (IJTSRD) ISSN: 2456-6470

\begin{tabular}{|c|c|c|c|c|c|c|c|c|}
\hline $\begin{array}{l}\text { S. } \\
\text { No }\end{array}$ & $\begin{array}{c}\text { Benefits of } \\
\text { mechanization }\end{array}$ & $\begin{array}{l}\text { Strongly } \\
\text { Agree }\end{array}$ & Agree & $\begin{array}{c}\text { Undeci } \\
\text { ded }\end{array}$ & Disagree & $\begin{array}{l}\text { Strongly } \\
\text { Disagree }\end{array}$ & TOS* & MOS* \\
\hline 6. & $\begin{array}{l}\text { Motivating workers to } \\
\text { acquire new skills and } \\
\text { competencies }\end{array}$ & - & $\begin{array}{c}139 \\
(86.88)\end{array}$ & $\begin{array}{c}16 \\
(10.00)\end{array}$ & $\begin{array}{c}5 \\
(3.12)\end{array}$ & - & 614 & 3.84 \\
\hline 7. & $\begin{array}{l}\text { Enhancing capacity } \\
\text { building of farmers }\end{array}$ & - & $\begin{array}{c}134 \\
(83.75) \\
\end{array}$ & $\begin{array}{c}24 \\
(15.00) \\
\end{array}$ & $\begin{array}{c}2 \\
(1.25) \\
\end{array}$ & - & 612 & 3.83 \\
\hline 8. & $\begin{array}{c}\text { Increasing the area } \\
\text { under rice cultivation }\end{array}$ & $\begin{array}{c}9 \\
(5.63) \\
\end{array}$ & $\begin{array}{c}125 \\
(78.12) \\
\end{array}$ & $\begin{array}{c}9 \\
(5.63) \\
\end{array}$ & $\begin{array}{c}17 \\
(10.62)\end{array}$ & - & 606 & 3.79 \\
\hline 9. & $\begin{array}{l}\text { Minimizing post- } \\
\text { harvest losses }\end{array}$ & $\begin{array}{c}11 \\
(6.88) \\
\end{array}$ & $\begin{array}{c}108 \\
(67.50) \\
\end{array}$ & $\begin{array}{c}21 \\
(13.12) \\
\end{array}$ & $\begin{array}{c}20 \\
(12.50)\end{array}$ & - & 590 & 3.69 \\
\hline 10. & $\begin{array}{c}\text { Increasing agricultural } \\
\text { productivity }\end{array}$ & $\begin{array}{c}6 \\
(3.75) \\
\end{array}$ & $\begin{array}{c}102 \\
(63.75) \\
\end{array}$ & $\begin{array}{c}45 \\
(28.13) \\
\end{array}$ & $\begin{array}{c}7 \\
(4.37) \\
\end{array}$ & - & 587 & 3.67 \\
\hline 11. & $\begin{array}{l}\text { Reducing cost of } \\
\text { cultivation }\end{array}$ & $\begin{array}{c}13 \\
(8.12) \\
\end{array}$ & $\begin{array}{c}88 \\
(55.00) \\
\end{array}$ & $\begin{array}{c}28 \\
(17.50) \\
\end{array}$ & $\begin{array}{c}31 \\
(19.38)\end{array}$ & - & 563 & 3.52 \\
\hline 12. & $\begin{array}{l}\text { Efficient utilization of } \\
\text { inputs }\end{array}$ & $\begin{array}{c}2 \\
(1.25) \\
\end{array}$ & $\begin{array}{c}88 \\
(55.00) \\
\end{array}$ & $\begin{array}{c}59 \\
(36.88) \\
\end{array}$ & $\begin{array}{c}11 \\
(6.87) \\
\end{array}$ & - & 561 & 3.51 \\
\hline 13. & $\begin{array}{c}\text { Enhancing integration } \\
\text { and cooperation among } \\
\text { farmers }\end{array}$ & & $\begin{array}{c}83 \\
(51.88) \\
\end{array}$ & $\begin{array}{r}74 \\
(46.25) \\
\end{array}$ & $\begin{array}{c}3 \\
(1.87)\end{array}$ & & 560 & 3.50 \\
\hline 14. & $\begin{array}{l}\text { Providing employment } \\
\text { opportunities to } \\
\text { educated unemployed } \\
\text { youth }\end{array}$ & $\begin{array}{c}2 \\
(1.25)\end{array}$ & $\begin{array}{c}46 \\
(28.75)\end{array}$ & $\begin{array}{c}70 \\
(43.75) \\
1210\end{array}$ & $\begin{array}{c}42 \\
(26.25)\end{array}$ & (a) & 488 & 3.05 \\
\hline 15. & $\begin{array}{c}\text { Attracting youth } \\
\text { towards agriculture }\end{array}$ & $\begin{array}{c}2 \\
(1.25) \\
\end{array}$ & $\begin{array}{c}43 \\
(26.88) \\
\end{array}$ & $\begin{array}{c}69 \\
(43.12) \\
\end{array}$ & $\begin{array}{c}46 \\
(28.75) \\
\end{array}$ & 2 & 481 & 3.01 \\
\hline \multicolumn{9}{|c|}{ Overall Mean Opinion Score $=3.91$} \\
\hline
\end{tabular}

It could be observed from Table 2 that 96.88 percent of the respondents strongly agreed and 3.12 per cent of the respondents agreed that farm mechanization helped in operating agricultural works quickly (MOS 4.97) followed by 86.25 per cent of the respondents strongly agreed and 13.75 per cent of the respondents agreed that farm mechanization helped in performing farm operations in time (MOS 4.86).

Exactly three fourths of the respondents (75.00 per cent) strongly agreed and the remaining one fourth of the respondents $(25.00$ per cent) agreed that farm mechanization helped in overcoming labour shortage problem (MOS 4.75) followed by just more than three fifths of the respondents (61.25 per cent) strongly agreed and the remaining 38.75 per cent of the respondents agreed that farm mechanization helped in minimizing work burden of labourers (MOS 4.61). The finding, farm mechanization helped in overcoming the labour shortage problem is in confirmation with the finding of (Thakur et al., 2016).
Most of the respondents ( 97.50 per cent) agreed and 2.5 per cent of the respondents strongly agreed that farm mechanization helped in improving working condition of farmers (MOS 4.03).

More than four fifths of the respondents ( 86.88 per cent) agreed that farm mechanization helped in motivating workers to acquire new skills and competencies (MOS 3.84) followed by 83.75 per cent of the respondents agreed that farm mechanization helped in enhancing capacity building of farmers (MOS 3.83) .

More than three fourths of the respondents $(78.12$ per cent) agreed and 5.63 per cent of the respondents strongly agreed that farm mechanization helped in increasing the area under rice cultivation (MOS 3.79). Similarly more than two thirds of the respondents (67.50 per cent) agreed and 6.88 per cent of the respondents strongly agreed that farm mechanization helped in minimizing post-harvest losses (MOS 3.69). 
More than three fifths of the respondents $(63.75$ per cent) agreed and 3.75 per cent of the respondents strongly agreed that farm mechanization helped in increasing agricultural productivity (MOS 3.67). The finding is in line with the finding of (Singh et al., 2011).

More than half of the respondents (55.00 per cent) agreed and 8.12 per cent of the respondents strongly agreed that farm mechanization helped in reducing cost of cultivation (MOS 3.52). This finding is in conformity with the finding of (Singh et al., 2011).

Similarly 55.00 percent of the respondents agreed and 1.25 per cent of the respondents strongly agreed that farm mechanization helped in efficient utilization of inputs (MOS 3.51).

Just more than half of the respondents (51.88 per cent) agreed that farm mechanization helped in enhancing integration and cooperation among farmers (MOS 3.50)
More than one fourth of the respondents (28.75 per cent) agreed and 1.25 per cent of the respondents strongly agreed that farm mechanization helped in providing employment opportunities to educated unemployed youth (MOS 3.05) followed by 26.88 per cent of the respondents agreed and 1.25 per cent of the respondents strongly agreed that farm mechanization helped in attracting youth towards agriculture (MOS 3.01).

The Overall Mean Opinion Score was 3.91 which indicated that farm mechanization was beneficial to the rice growers in many aspects.

\subsection{Constraints encountered by rice growers in mechanization}

An attempt was made to assess the constraints faced by the respondents in adoption of farm mechanization in rice cultivation in Thamirabarani command area of Tamil Nadu and the results are given in Table 2.

Table 2.Constraints encountered by rice growers in mechanization

\begin{tabular}{|c|c|c|c|}
\hline S. No & Constraints & Number & Per cent \\
\hline 1. & Lack of credit facilities & 158 & 98.75 \\
\hline 2. & Develonment & 158 & 98.75 \\
\hline 3. & High initial cost & 156 & 97.50 \\
\hline 4. & Low resale value for farm implements and machineries & 156 & 97.50 \\
\hline 5. & High maintenance cost & 152 & 95.00 \\
\hline 6. & Lack of training on use of farm implements and machineries & 151 & 94.38 \\
\hline 7. & $\begin{array}{l}\text { Lack of skilled labourers for operating improved farm implements and } \\
\text { machineries }\end{array}$ & 149 & 93.13 \\
\hline 8. & High tax rate & 135 & 84.38 \\
\hline 9. & High hiring charges & 133 & 83.13 \\
\hline 10. & Inadequate hiring agencies & 98 & 61.25 \\
\hline 11. & Frequent repairs & 79 & 49.38 \\
\hline 12. & Low efficiency & 47 & 29.38 \\
\hline 13. & Lack of awareness about improved farm machineries & 38 & 23.75 \\
\hline 14. & Non-availability of suitable farm implements and machineries & 32 & 20.00 \\
\hline 15. & Unsuitable farm implements and machineries & 32 & 20.00 \\
\hline 16. & Inadequate repair and service facilities & 30 & 18.75 \\
\hline 17. & Lack of availability of spare parts & 27 & 16.88 \\
\hline
\end{tabular}

It is evident from Table 2 that most of the respondents reported financial constraints such as lack of credit facilities (98.75 per cent), high fuel cost (98.75 per cent), high initial cost (97.50 per cent), low resale value for farm implements and machineries ( 97.50 per cent) and high maintenance cost ( 95.00 per cent) as the major constraints in the use of tools, implements and machineries in rice cultivation. The findings derive support from the findings of (Wang, 2003) who reported high initial cost of machineries as the constraint in farm mechanization. 
More than ninety per cent of the respondents (94.38 per cent) expressed lack of training on use of farm implements and machineries as the constraint. This finding is in conformity with the findings of (Vanetha, 2006) and (Thakur et al., 2016).

Lack of skilled labourers for operating improved farm implements and machineries was reported as constraint by 93.13 per cent per cent of the respondents. The finding is in accordance with the findings of (Patil et al., 2001) and (Vanetha, 2006) who also reported lack of skilled labourers for operating farm implements and machineries as constraint for mechanization.

More than four fifths of the respondents stated high tax rate (84.38 per cent) and high hiring charges (83.13 per cent) as constraints in rice mechanization. The findings are in agreement with the findings of (Anandaraja, 1999) who reported high hiring charges as constraint for mechanization.

Just more than three fifths of the respondents $(61.25$ per cent) expressed inadequate hiring agencies in their area as the constraint. The finding is in line with the findings of (Panghal and Deep, 2006) who also reported low custom hire facilities as constraint.

A frequent repair was reported as constraint by nearly half of the respondents (49.38 per cent). Low efficiency of implements and machineries was reported as constraint by 29.38 per cent of the respondents. This finding is in accordance with the finding of (Wang, 2003) who reported low efficiency of implements and machineries.

Lack of awareness about improved farm machineries was reported as constraint by 23.75 per cent of the respondents. The finding is in conformity with the findings of (Bhatia, 1986), (Vanetha, 2006) and (Thakur et al., 2016) who reported lack of awareness about improved farm machineries as constraint for mechanization in their studies.

Exactly one fifth of the respondents (20.00 per cent) stated non-availability of suitable farm implements and machineries and unsuitable farm implements and machineries as the constraints in rice mechanization in Thamirabarani command area.

Inadequate repair and service facilities was reported as constraint by 18.75 per cent of the respondents.
This finding is supported by the findings of (Patil et al., 2001), (Panghal et al., 2006), and (Singh et al., 2011) who also reported inadequate repair and service facilities.

Lack of availability of spare parts was stated as constraint by 16.88 per cent of the respondents. This finding draws support from the findings of (Patil et al., 2001) who reported lack of availability of spare parts as constraint.

\section{Conclusion}

The study focused on the opinion of the rice growers on the benefits of farm mechanization revealed that farm mechanization was beneficial to the rice growers in many aspects. The major benefits of farm mechanization as perceived by the respondents were that farm mechanization helped in operating agricultural works quickly, performing farm operations in time, overcoming labour shortage problem, minimizing work burden of labours and improving working condition of farmers. The study identified many constraints in farm mechanization Majority of the respondents expressed lack of credit facilities, high fuel cost, high initial cost, low resale value for farm implements and machineries, high maintenance cost, lack of training on use of farm implements and machineries, Lack of skilled labourers for operating improved farm implements and machines, high tax rate, high hiring charges and inadequate hiring agencies as the major constraints in rice mechanization. Specific strategies should be evolved by the change agency to eliminate the constraints experienced by the rice growers for enhancing rice mechanization in Thamirabarani command area.

\section{References}

1. Anandaraja, N. (1999). Farm mechanization in Tamil Nadu: Issues and prospect. (Unpub. M.Sc. (Ag.) Thesis), TNAU, Coimbatore.

2. Bhatia, B. S. (1986). Multivariate study of adoption of selected agricultural engineering technologies in the Punjab. (Ph.D. Thesis), PAU, Ludhiana.

3. Panghal, B. S., \& Deep, P. (2006). Emerging problems of farm mechanization in Karnal district of Haryana State. Agricultural Science Digest, 26(4), 253-256. 
4. Patil, V. G., Chorge, K. V., \& Desai, A. N. (2001). Constraints in the use of improved farm implements. Maharashtra Jour. of Extn. Edu, 20.

5. Rasouli, F., Sadighi, H., \& Minaei, S. (2009). Factors affecting agricultural mechanization: A case study on sunflower seed farms in Iran. J. Agric. Sci. Technol., 11, 39-48.

6. Singh, T. V., Kumar, R. M., \& Viraktamath, B. (2011). Selective mechanization in rice cultivation for energy saving and enhancing the profitability. Research themes, Rice Knowledge Management Portal (RKMP), Directorate of rice research, Rajendranagar, Hyderabad, 1-14.
7. Thakur, P., \& Sharma, D. (2016). Farmers' satisfaction with the use of modern farm mechanization. International Journal of Applied and Pure Science and Agriculture (IJAPSA), 2(8), 165-170.

8. Vanetha, K. P. (2006). Utilization Behaviour of Farm Equipment in Commercial Crops. TNAU, Coimbatore.

9. Wang, Z. (2003). The challenges to and technical innovations in the mechanization of rice production in China. Paper presented at the International Rice Research Conference,, Beijing, China, 16-19 September 2002.

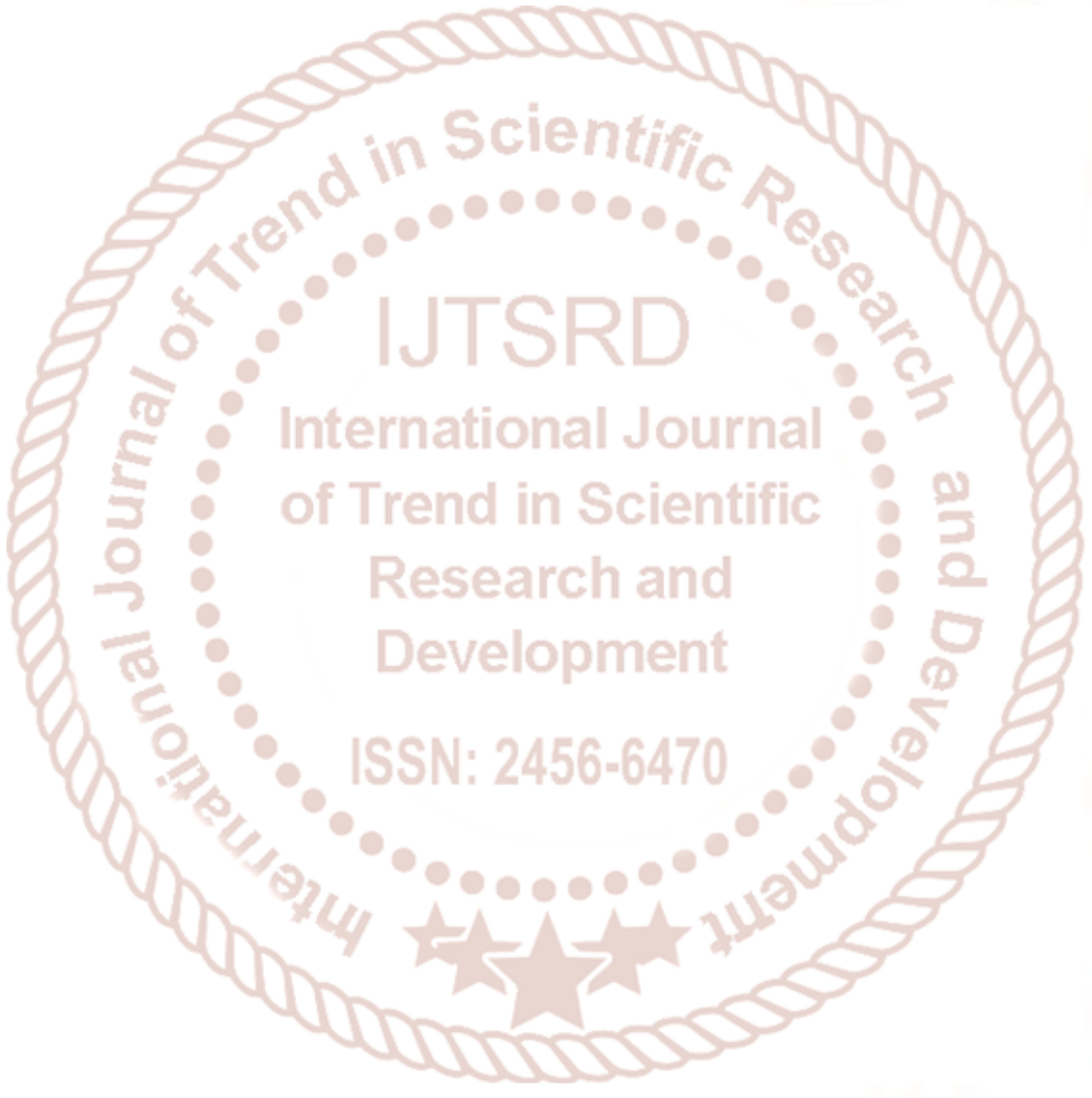

